УДК 808.51:324-05

DOI https://doi.org/10.32838/2663-6069/2019.4-2/07

Humeniuk N. H.

Borys Grinchenko Kyiv University

\title{
STORYTELLING TECHNIQUE IN THE BORIS JOHNSONS' FIRST SPEECH AS A PRIME MINISTER, 07. 24. 19
}

\begin{abstract}
The following work is devoted to the problem of storytelling technique within the Boris Johnsons' first speech as a Prime Minister of the UK, 07.24.19. It is stated that the Boris Johnsons'first speech as a Prime Minister of the UK is a political, institutional, ideological, media and mass-communicative discourse with the focus on the idea of Brexit, or withdrawal from the EU, as the most relevant idea for the UK community. It is pointed out that Boris Johnsons'speech has the features of narrative. It is underlined that Boris Johnsons'message has the narrative structure: introduction, main body and end. It is stated that Boris Johnsons'first speech as a Prime Minister of the UK contains the theme and the idea of it, where the theme is Boris Johnsons' appointment as a Prime Minister and future plans of the UK development as realization of his Cabinet policy, and the idea of it is the necessity to implement Brexit as the only way for better life in the UK. It is stressed that the Boris Johnsons' first speech as a Prime Minister of the UK contains the division into enemies and heroes. The opponents of Brexit are shown as enemies in Boris Johnsons' speech and his team with the UK population is shown as heroes struggling with the enemies for their values - Brexit. Heroes are known to have their potential, as well as certain plan to win enemies. It is stressed in Boris Johnsons'speech that the condition of their victory against enemy is their being ready for Brexit and their being united. The end of the Boris Johnsons'story is optimistic, as enemies will not succeed. It is stated that Boris Johnsons'story resembles fairy-tale with its happy end. It is underlined that storytelling technique as part of manipulative one is used to influence addressee for the pragmatic purposes of speaker. It is stressed that storytelling technique of the Boris Johnsons' first speech as a Prime Minister of the UK is focused on the problem of addressee acceptance of Brexit. It is stated that storytelling technique in Boris Johnsons'speech is grounded on speaker's depiction of real facts issued for real facts, is based on hero/enemy separation, on enemy imaging, on enemy fighting and imminent victory over enemy.
\end{abstract}

Key words: storytelling, ideological discourse, narrative, pragmatic purpose, addressee

\section{Problem statement.}

Narrative as one the most investigated problem is also one of the most contradictive item in linguistics. In our work we use term storytelling to show narrative as a process of introducing information in a form of a certain story with emphasis on the pragmatic purposes of its creator, as a certain technique to influence addressee for the addressor's intentions.

Literature review

The problem of narrative shows the different approaches to it, changes in the system of civilization knowledge is reflected in system of narrative understanding $[1 ; 2 ; 3 ; 8 ; 9 ; 10 ; 11 ; 12]$.

In our work we define narrative as: 1) a way of reality reflection with the emphasis on its time and place occurrence, or its space and time location; 2) a way of introducing, coding information in a form of a story as the most suitable form of its perception ; 3) a form of storing knowledge from generation to generation with emphasis on its cultural, religious, regional, group, community identity; 4) a certain type of text not discourse; 5) a genre of literary work. Storytelling, in this case, is defined in our work as a means to introduce information in a form of a story to realize its creator purposes to influence addressee.

The aim of the paper is to investigate storytelling technique of the Boris Johnsons' first speech as a Prime Minister of the UK, 07.24.19, as the way to realize his pragma-communicative purposes.

\section{The material of the article}

The first speech of Boris Johnson as a Prime Minister is considered to be the political, institutional discourse as 1) it is produced by the representative of the political elite - by Prime Minister, or it has statute-role characteristics; 2) it contains the aim of communication to influence the addressee - the UK population; 3 ) it has typical place of its realization - the Prime Minister's Office, 10, Downing Street [5,39; 4, 44] and 4 ) it has certain norms of language usage within the given type of discourse.

The first speech of Boris Johnson as a Prime Minister is defined in our work as ideological discourse 
[7,18-19], which contains an idea of Brexit, or withdrawal from the EU, as the most relevant to the community of the UK for better life in the country.

In accordance to the number of communicators the first speech of Boris Johnson as a Prime Minister is known to be mass-communicative discourse [6, 135-136] and its realization through the mass media makes it media discourse.

The first speech of Boris Johnson as a Prime Minister is considered to have the informative and pragmatic component. The informative component of it is based on the information about the policy line of his Cabinet in the external and internal politics, which is centered on the idea of Brexit as the most relevant way to develop the UK society.

As for its pragmatic component, its aim is to influence addressee to accept the idea of Brexit as the most relevant and the only one way for better life in the UK.

The first speech of Boris Johnson as a Prime Minister is pointed out in our work as monologue in its form addressed to the certain addressee, which is transformed in a dialogue without any chances to be replied or be answered, without any speech act from the addressee, whom this discourse is addressed.

In his speech Boris Johnsons uses addresses for the citizens of the UK, non-citizens of the UK working and living in it and his opponents for the idea of Brexit.

To realize his purpose - to influence addressee he uses certain techniques, tactics, among which is storytelling technique as part of the manipulative one.

It is stated in our work that the first speech of Boris Johnson as a Prime Minister has all the features of narrative.

The theme of the first speech of Boris Johnson as a Prime Minister is his appointment to this position and future plans of the UK development in the form of withdrawal from the EU:

I have just been to see Her Majesty the Queen who has invited me to form a government and I have accepted. .... we are going to restore trust in our democracy and we are going to fulfil the repeated promises of parliament to the people and come out of the EU on October $31 \ldots$.

Consequently, the main idea of his speech is the necessity to implement Brexit:

...we will do a new deal, a better deal that will maximise the opportunities of Brexit while allowing us to develop a new and exciting partnership with the rest of Europe based on free trade and mutual support.

We can also state that Boris Johnsons appeals to much more ambitious idea to restore glorious global nature of the UK: ...it is time to change the record to recover our natural and historic role as an enterprising, outward-looking and truly global Britain, generous in temper and engaged with the world.

The type of narration the Boris Johnson's first speech as a Prime Minister is subjectivized, or given from the first person singular $(I)$ or plural (we):

1. And so I am standing before you today to tell you the British people that those critics are wrong.

2. My job is to make your streets safer - and we are going to begin with another 20,000 police on the streets and we start recruiting forthwith.

Narration from the first person plural within the political, ideological discourse is a specific feature to show team responsibility for the described events.

The given speech of Boris Johnsons has the narrative structure: the introduction, the main body and the end.

The introduction contains the information about Teresa May resign and Boris Johnsons' appointment of a Prime Minister. The main body is focused on the problem of Brexit. The end of narrative is optimistic.

We can state, that, the first speech of Boris Johnson as a Prime Minister is a story of conflict, which contains the main protagonists: heroes and enemies.

According to Boris Johnsons' vision, his nation with his team and himself are the main heroes of his story struggling with the Brexit opponents, who fulfil the role of enemies in his story, for their democratic values:

...there are pessimists at home and abroad who think that after three years of indecision that this country has become a prisoner to the old arguments of 2016. ...And so I am standing before you today to tell you the British people that those critics are wrong The doubters, the doomsters, the gloomsters - they are going to get it wrong again. The people who bet against Britain are going to lose their shirts.

Heroes have the great potential to fight their enemies:

.... we know the enormous strengths of this economy in life sciences, in tech, in academia, in music, the arts, culture, financial services, It is here in Britain that we are using gene therapy, for the first time, to treat the most common form of blindness here in Britain that we are leading the world in the battery technology that will help cut $\mathrm{CO} 2$ and tackle climate change and produce green jobs for the next generation.

Heroes also have a certain plan to fight the enemies, to realize the idea of Brexit, which is introduced in Boris Johnsons' speech as series of calls to act:

1. Let us begin work now to create free ports that will drive growth and thousands of high-skilled jobs in left behind areas. 
2. Let's start now to liberate the UK's extraordinary bioscience sector from anti genetic modification rules.

3. Let's develop the blight-resistant crops that will feed the world.

4. Let's get going now on our own position navigation and timing satellite and earth observation systems - UK assets orbiting in space with all the long term strategic and commercial benefits for this country

5. Let's change the tax rules to provide extra incentives to invest in capital and research.

6. Let's promote the welfare of animals that has always been so close to the hearts of the British people and yes, let's start now on those free trade deals.

The heroes of the Boris Johnsons story need some conditions to realize their plan: being united and being ready:

....under any circumstances we will need to get ready at some point in the near future to come out of the EU customs union.. with high hearts and growing confidence we will now accelerate the work of getting ready and the ports will be ready and the banks will be ready and the factories will be ready and business will be ready and the hospitals will be ready and our amazing food and farming sector will be ready...

The end of this story is hopeful in future perspective, it resembles happy end of fairy tale, as enemies will not succeed:

No one in the last few centuries has succeeded in betting against the pluck and nerve and ambition of this country. They will not succeed today.

So, the plot of the Boris Johnsons story may be compressed to the given model: We, the UK nation and my team with me, try to make our life better implementing the idea of Brexit as the most relevant for the UK community. On our way for it we have some enemies - opponents for Brexit. We can fight them and we'll win them, they will not succeed.

We can state that the story telling technique within the Boris Johnsons speech is a part of manipulative technique, when the vision of the addressor of information is given as some kind of truth, as real facts. The separation into enemies and heroes is doubtful, because opponents to somebody's position don't mean enemy to the whole nation, and it is questionable, whose role in the history of the country is more harmful and more useful. Moreover, opponents are a necessary factor to move ahead, to see strong and weak points, to find the best ways of problem solution.

\section{Conclusions}

Summing up the material, we'd like to state that the Boris Johnsons' first speech as a Prime Minister of the UK, 07.24.19, has the features of narrative: the main idea, theme, the main characters, the structure of narrative. Moreover, it resembles fair-tale with its optimistic end.

We'd like also to state that the Boris Johnsons' first speech as a Prime Minister of the UK, as a political, institutional, ideological, media and mass-communicative discourse includes storytelling technique to influence addressee. This technique is based on introducing speaker's vision of real facts as real facts, as some truth and also is based on hero/enemy separation, on enemy imaging, on enemy fighting and victory over enemy.

It's rater prospective to investigate idiolect and idiostyle of Boris Johnsons as a Prime Minister, to investigate manipulative component of his speeches.

\section{References:}

1. Брокмейер И., Харре Р. Нарратив проблемы и обещания одной альтернативной парадигмы. Bonpocы философии. 2000. №3 . С. $29-42$.

2. Верменич Я. В. Локально-регіональні рівні вітчизняного наративу. Украйнський історичний журнал. 2013. № 5. C. $4-23$.

3. Дьяковська Г. Наратив як складова дискурсивної реальності. Схід. № 5 (151). Філософські науки. 2017. C. $70-73$.

4. Карасик В. И. Этнокультурные типы институционального дискурса. Этнокультурная специфика речевой деятельности. Сб. обзоров. М.: ИНИОН РАН , 2000. С. $37-64$.

5. Рябоконь Г. Л. Дискурсивні особливості інтернет публікацій дебатів Британського парламенту : дис. ...канд. філол. наук : 10.01.08. Нац. ун-т «Київо-Могилянська академія». К., 2009. 276 с.

6. Селіванова О. О. Опозиція свій - чужий в етносвідомості ( на матеріалі українськиї перемій ). Мовознавство. К., 2005. №1. С. $26-34$.

7. Тхоровська С. В. Ідеологічний дискурс англомовної преси (лінгвокогнітивні аспекти) : дисс ...канд. філол. наук: 10.02.04. Львівський національний університет імені І. Франка. Львів, 2010. 230 с.

8. Фуко М. Археологія знання : пер. $з$ фр. Шовкун В. К. : Вид-во Соломії Павличко «Основи», 2003. 328 c.

9. Carr D. Narrative and the Real World : an argument for Continuity. History and Theory. 1988. Vol. 25. N 2. $117-131$ 
10. Estaban-Guitart M. Towards a Multimethodological Approach to Identification of Funds of Identity, Small Stories and Master Narratives. Narrative Inquiry 22:1. John Benjamins Publishing Company, 2012. P. 174 -180.

11. Mink L. O. Narrative Form as a Cognitive Instrument. Writing of History, Literary Form and Historical Understanding : ed. by R. H. Canary and H. Cozik . Madison, 1978. $129-149$.

12. Torfing J. Discourse Theory: Achievements, Arguments and Challenges. Discourse Theory in European Politics, Identity, Policy and Governance. Palgrave Macmilan, 2005. 349 p.

\section{ГУМЕНЮК Н. Г. ТЕХНІКА СТОРІТЕЛІНГУ У ПЕРШІЙ ПРОМОВІ БОРИСА ДЖОНСОНА ЯК ПРЕМ' ЄР МІНІСТРА ОБ'ЄДНАНОГО КОРОЛІВСТВА ВІД 24.07.19}

Подана робота присвячена розгляду техніки сторітелінгу у першій промові Бориса Джонсона у якості Прем'єр міністра Об'єднаного Королівства від 24.07.19. як політичного, інституційного, ідеологічного, медійного, масово-комунікативного дискурса з фокусуванням на ідеї Брекзиту, або виходу з ЄС, як найбільш релевантній ідеї для спільноти Об'єднаного Королівства. Підкреслюється, щзо промова Бориса Джонсона має всі ознаки наративу. Визначається, що послання Бориса Джонсона має структуру наратива: введення, головна частина, закінчення. Стверджується, що перша промова Бориса Джонсона як Прем'єр міністра Об'єднаного Королівства містить в собі тему та ідею, де тема пов'язана з призначенням Бориса Джонсона Прем'єр міністром Об'єднаного Королівства та подальшими планами розвитку країни як реалізачія політики його Кабінету, а ідея його промови визначається як необхідність здійснення Брекзиту як єдиного способу покрашити життя в Об 'єднаному Королівстві. Підкреслюється, що перша промова Бориса Дюсонсона як Прем'єр міністра Об 'єднаного Королівства містить розподіл на героїв та ворогів. Опоненти до Брекзиту постають як вороги у першій промові Бориса Джонсона, його команда разом з населенням Об'єднаного Королівства постають як герої у їхній боротьбі за свої цинності - за Брекзит. Як відомо, герої мають певний потенціал та план перемогти ворога. У першій промові Бориса Джонсона підкреслюється, що необхідні певні умови для перемоги над ворогом: бути єдними та готовими до здійснення Брекзиту. Кінцівка розповіді Бориса Джонсона оптимістична, так як вороги не матимуть успіху. Стверджується, що розповідь Бориса Джсонсона нагадує казку зі щасливим ї̈ завершенням. Підкреслюється, щяо техніка сторітелінгу як частина маніпулятивної техніки використовується для впливу на адресата з прагматичними намірами промовия. Зауважується, що техніка сторітелінгу у першій промові Бориса Джонсона Джонсона як Прем'єр міністра Об'єднаного Королівства сфокусована на проблемі прийняття адресатом ідеї Брекзита. Стверджується, щьо техніка сторітелінгу у промові Бориса Джонсона базується на зображенні автором фактів, які видається за реальність, на розподілі на ворогів та героїв, на складанні образу ворога, необхідності боротьби з ним та неодмінній перемоги над ним.

Kеу words: сторітелінг, ідеологічний дискурс, наратив, прагматична мета, адресат. 